\title{
First report of Didymella bellidis causing leaf spots on Angelica gigas in South Korea
}

\author{
Dong-Hyeon Lee ${ }^{1}$ (D) $\cdot$ Ki Man Choi $^{2} \cdot$ Chung Ryul Jung $^{3} \cdot$ Sang-Hyun Lee ${ }^{1}$
}

Received: 3 March 2020 / Accepted: 12 May 2020 / Published online: 3 June 2020

(C) Società Italiana di Patologia Vegetale (S.I.Pa.V.) 2020

Keywords Umbelliferae $\cdot$ Medicinal plant $\cdot$ Fungal diseases $\cdot$ Seedling

Angelica gigas Nakai (Umbelliferae) is cultivated as a medicinal plant in East Asia. In 2019, pale to dark-brown, orbicular to irregular, $0.5-1.7 \mathrm{~cm}$ in diam. leaf spots, which often merged to form larger blotches on the surface of mature leaves, were observed in Bonghwa $\left(35^{\circ} 00^{\prime} 32.4^{\prime \prime} \mathrm{N} 126^{\circ} 49^{\prime} 17.6^{\prime \prime} \mathrm{E}\right)$ and Yeongyang $\left(36^{\circ} 51^{\prime} 21.8^{\prime \prime} \mathrm{N} 129^{\circ} 11^{\prime} 03.0^{\prime \prime} \mathrm{E}\right)$, in Gyeongsangbuk province of South Korea. The fungus was isolated from the margins of spots. White to light grey, gradually turning to olivaceous grey colonies were produced on $2 \%$ malt extract agar after 14 days of incubation. Axenic cultures prepared from single conidia produced pycnidia which were dark, globose to subglobose, 149.5-197.8 × 115.1-213.9 $\mu \mathrm{m}$. Conidia were smooth, oval, 1-celled, usually guttulate, 3.7$6.3 \times 1.9-2.5 \mu \mathrm{m}$. Morphological characteristics suggested that the fungus is Didymella bellidis (Neerg.) Qian Chen \& L. Cai (de Gruyter et al. 1993; Chen et al. 2015). The fungus was deposited in Culture Collection, National Institute of Forest Science, South Korea (CDH2019-6-7). DNA of the fungus was extracted and amplified, and the ITS and $\beta$-tubulin genes (GenBank MT114578-9, MT121110-1) were sequenced. A BLASTn analysis showed $99 \%$ identity of the studied isolate with $D$. bellidis (GU237904 for ITS, GU237586 for $\beta$-tubulin) (Chen et al. 2015). A pathogenicity test was carried out on ten 8 -week-old plants of A. gigas. Leaves of each plant were

Dong-Hyeon Lee

leedh2009@SouthKorea.kr

1 Division of Forest Insect Pests and Diseases, National Institute of Forest Science, Seoul 02455, South Korea

2 Gangwon Nature Environment Research Park, Hongcheon, South Korea

3 Forest Medicinal Resources Research Center, National Institute of Forest Science, Yeongju 36040, South Korea sprayed with $10 \mathrm{ml}$ of conidial suspension $\left(10^{5}\right.$ conidia/ml, isolate CDH2019-6). Five control plants were sprayed with sterile water. After 14 days, in the greenhouse, at $25^{\circ} \mathrm{C}$ and $80 \%$ relative humidity, the leaf spots appeared. Didymella bellidis was re-isolated from $85 \%$ of spots, fulfilling Koch's postulates. This is the first report of $D$. bellidis on A. gigas in South Korea (Farr and Rossman 2020).

Acknowledgements The authors acknowledge the financial support from the National Institute of Forest Science, 'Development of management tools for insect pests and fungal pathogens occurring on forest tree crops, no. FP0802-2017-02'.

\section{Compliance with ethical standards}

Conflict of interest The authors have no conflicts of interest to declare.

Ethical statements All the authors have sufficiently contributed to the work, have agreed to this submission and are responsible for its contents. This manuscript including the data that are supporting the aim and the conclusion of this research is new and is not being considered elsewhere. No data have been fabricated or manipulated for being published to the journal.

\section{References}

Chen Q, Jiang JR, Zhang GZ, Cai L, Crous PW (2015) Resolving the Phoma enigma. Stud Mycol 82:137-217

de Gruyter J, Noordeloos ME, Boerema GH (1993) Contributions towards a monograph of Phoma (Coelomycetes) - I. 2. Section Phoma: additional taxa with very small conidia and taxa with conidia up to $7 \mu \mathrm{m}$ long. Persoonia 15:369-400

Farr DF, Rossman AY (2020) Fungal Databases, U.S. National Fungus Collections, ARS, USDA. https://nt.ars-grin.gov/fungaldatabases/ fungushost/fungushost.cfm. Retrieved February, 2020

Publisher's note Springer Nature remains neutral with regard to jurisdictional claims in published maps and institutional affiliations. 